\title{
ANTI-TMV ACTIVITIES OF PANTOEA AGGLOMERANS LIPOPOLYSACCHARIDES IN VITRO
}

\author{
T.V. Bulyhina, A.M. Kyrychenko, M.S. Kharchuk, L.D. Varbanets \\ Zabolotny Institute of Microbiology and Virology, NAS of Ukraine, \\ 154 Acad. Zabolotny Str., Kyiv, 03143, Ukraine \\ e-mail:tati20@ukr.net
}

\begin{abstract}
Today there are no antiviral drugs of chemical nature that can completely cure virus-infected plants. The fact that their effect is limited to minimizing the pathogenic effect of viruses motivates many researchers to look for alternatives. In recent years it has been shown that lipopolysaccharides (LPS) of some bacteria, in particular representatives of the Pseudomonas genus were active against Tobacco mosaic virus (TMV). Therefore, we were interested in the additional study of LPS of phytopathogenic bacteria Pantoea agglomerans as a possible drug acting as antiviral agent. The aim of current study was to evaluate the antiviral activities of LPS obtained from phytopathogenic bacteria P. agglomerans against TMV in vitro. Methods. The antiviral activity of LPS preparations was investigated in vitro and assessed according to the inhibition percentage towards the number of local lesions in Datura stramonium leaves. P. agglomerans LPS was isolated from dry bacterial mass by phenol-water method. LPS mild acid degradation allowed to separate O-specific polysaccharide (OPS) and lipid A, which structures were identified by us earlier. The analysis of TMV and LPS interactions was carried out using a JEM 1400 transmission electron microscope (Jeol, Japan) at an accelerating voltage of $80 \mathrm{kV}$. Results. The most active were LPS preparations from P. agglomerans P324 and 8488. In vitro inhibitory efficacies of TMV infection by these LPS preparations was 59 and $60 \%$ respectively. LPS preparations of P. agglomerans 7969, 7604 and 9637, on the contrary, were inactive. Comparative analysis of the antiviral activity of LPS structural components of two P. agglomerans P324 and 7604 strains showed that the greatest inhibitory effect on the infectivity of TMV was exhibited by P. agglomerans P324 lipid A, the antiviral activity of which practically did not differ from the activity of the LPS molecule (it was lower by $7 \%$ ). At the same time, the inhibitory effect of P. agglomerans 7604 core oligosaccharide (OG-core) against TMV was slightly higher compared to the effect of the whole LPS molecule. It can be assumed that the OG-core stimulated the defense mechanisms of plants and prevented the development of viral infection. Electron microscopic dates have shown that P. agglomerans P324 LPS at the concentration of $1 \mathrm{mg} / \mathrm{ml}$ influenced on freely located virions in the control causing "sticking" thus forming dense clusters, complexes or "bundles" of the virus. The individual structural components of P. agglomerans P324 LPS (lipid A and OG-core) did not have the same effect as a whole molecule. Conclusions. The study of the antiviral activity of LPS in the model system TMV-Datura stramonium L. plants showed that the most active were LPS preparations of only two strains of P. agglomerans (P324 and 8488) while the other seven strains were inactive. Individual structural components: lipid A from P. agglomerans P324 and OG-core from P. agglomerans 7604 decreased the infectivity of TMV by 7 and $15 \%$ higher than the initial LPS molecule. According to electron microscopy data the virions sticked together forming the dense clusters in case of the direct LPS-virus contacting in vitro whereas in the control it was observed just a single free virus particles. A more detailed study of the effect of individual structural components will help to understand the regularities of the LPS structure effect on TMV infectivity.
\end{abstract}

Keywords: Pantoea agglomerans, lipopolysaccharides, lipid A, core oligosaccharide, tobacco mosaic virus, infectivity inhibition, electron microscopy.

Plant viral diseases are widespread in agro- and biocenoses, causing significant economic damage to crop production [1]. Viruses in their harmfulness are often superior to other pathogens including phytopathogenic fungi. These viruses include the Tobacco mosaic virus (TMV), which primarily infects crops such as cucumbers, tomatoes, potatoes, tobacco and peppers. Given the facts that viruses are obligate intracellular plant parasites, the main methods of plant viruses controlling are reduced mainly to preventing infection and developing new antiviral means and(or) approaches 
for crop protection. At the same time, the list of effective and environmentally safe antivirals is extremely limited. Currently known antiviral drugs (ningnanmycin and ribavirin) have a weak antiviral effect and lead to curative rates of 30-60\% [2, 3]. Chemicals effective against pathogens of viral diseases, as a rule, are characterized by significant phytotoxicity [4], moreover, they complicate the problems of ecological balance in the environment.

Thus the search for new compounds continues, and in recent years the development of environmentally friendly biological antiviral agents as an alternative to chemicals is becoming a major area of research for prevention of attack by plant viruses. It's known [5] that the antiviral effect of a number of natural substances of certain plant extracts does not exceed 40-50 \%. Few reports indicate that some bacteria and yeasts $[6,7]$ are capable of exhibiting antiviral activity. Thus, recently it has been shown that lipopolysaccharides (LPS) of some bacteria, in particular representatives of the genus Pseudomonas, play a significant role in the interaction of plants with pathogens [8]. They activate and trigger the expression of plant defense mechanisms in response to infection caused by fungi or bacteria but their effect on plant viruses remains poorly understood. Previously [9], we studied and established for the first time the antiviral properties of Pseudomonas chlororaphis subsp. aureofaciens LPS. The representatives of this species are widely used for biological protection of agricultural crops from pests and pathogens. It was found that LPS from $P$. chlororaphis subsp. aureofaciens UCM B-111 and UCM B-306 are components of integrated insectofungicidal preparation "Gaupsin" with a sufficiently high efficiency against TMV $[10,11]$. Therefore, we were interested in studies of LPS obtained from such phytopathogenic bacteria as Pantoea agglomerans for antiviral activity against TMV as possible components of complex drugs against plant pathogens. The aim of current study was to evaluate the antiviral activities of LPS obtained from phytopathogenic bacteria P. agglomerans against TMV in vitro.

Materials and methods. The objects of research were LPS of nine $P$. agglomerans strains isolated from different plants and geographic zones: 1 $8674^{\mathrm{T}}$ (cereals, Canada); 2 - 7460 (rye, Dniprovsk region, Ukraine); 3 - 7460suc (succinylated LPS); 4 - P1a (wheat, Kherson region, Ukraine); 5 - P324 (wheat, Kherson region, Ukraine); 6 - 8488 (oats, Romania); 7 - 7969 (apple tree, Minsk, Belarus); 8 - 7604 (rye, Kyiv region, Ukraine); 9 - 9637 (wheat, Kyiv region, Ukraine); 10 - 9649 (wheat, Kyiv region, Ukraine).

The bacteria were grown on potato agar during $36 \mathrm{~h}$ at $28-30{ }^{\circ} \mathrm{C}$. The cells were collected by centrifugation (20 min, $5000 \mathrm{~g}$ ), washed with saline, and dried by treatment with acetone and ether. LPS from dried cells was extracted with $45 \%$ aqueous phenol solution at $65-68{ }^{\circ} \mathrm{C}$. The resulting aqueous fractions were dialyzed in tap and then distilled water to eliminate phenol.

LPS modification was carried out by succinylation [12]. $0.5 \mathrm{ml}$ of distilled pyridine was added to $5 \mathrm{mg}$ of LPS and the mixture was kept in a drying cabinet at $100{ }^{\circ} \mathrm{C}$ during $1 \mathrm{~min} .0 .4 \mathrm{ml}$ of succinic anhydride solution in pyridine was added to the sample after cooling mixture to room temperature. The samples were incubated during $30 \mathrm{sec}$ at $100{ }^{\circ} \mathrm{C}$ in a water bath and hydrolyzed during 3 hours at $56^{\circ} \mathrm{C}$. After cooling, the mixture was dialyzed in distilled water during 48 hours at room temperature, neutralized with $0.1 \mathrm{~N} \mathrm{NaOH}$

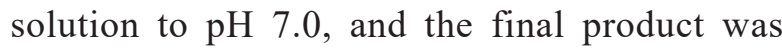
lyophilized [12].

Degradation of LPS was carried out by mild acid hydrolysis with $1-4 \%$ acetic acid at $100{ }^{\circ} \mathrm{C}$ during 1.5-6 h (depending on the strain) until an insoluble precipitate formed. The lipid A precipitate was separated by centrifugation $(25000 \mathrm{~g}$, $40 \mathrm{~min}$ ), and the supernatant (carbohydrate part of LPS) was concentrated to a volume of $\sim 7-8 \mathrm{ml}$ and fractionated on a column $(70.0 \times 3.0 \mathrm{~cm})$ with Sephadex G-50 using $0.25 \mathrm{~N}$ pyridine acetate buffer $(\mathrm{pH}=4.5)$. Elution profiles were constructed based on the determination of carbohydrate fractions by the phenol-sulfur method [13].

The TMV (strain U1) was propagated in Nicotiana tabacum L. varieties Immunny 580 (revertant) and purified as described by Hebert [14]. The antiTMV activity of LPS was tested using the halfleaf method $[15,16]$. Control half of leaves were inoculated by rubbing them with a brush dipped in virus-buffer suspension. The experimental half of leaf was inoculated with virus-LPS mixtures.

The antiviral activity of LPS preparations was investigated in vitro and assessed according to the inhibition percentage towards the number of local lesions in Datura stramonium leaves. The viral suspension (TMV concentration $0.2 \mu \mathrm{g} / \mathrm{ml}$ ) was mixed with LPS $(1 \mathrm{mg} / \mathrm{ml})$ at a $1: 1$ ratio and incubated under the laboratory conditions. After 30 min Datura stramonium leaves were inoculated with the virus/LPS mixtures. The Datura stramonium leaves inoculated with $50 \mathrm{mM}$ phOPShate buffer ( $\mathrm{pH}$ 6.8) instead of LPS solutions 
were used as a control of TMV suspension. Ten leaves were used for each type of treatment and in 5-6 days after the inoculations the local lesion numbers were recorded.

The studies were performed in triplicate in spring and summer in greenhouse condition, with an average daily air temperature of $25-33^{\circ} \mathrm{C}$.

The antiphytoviral inhibitory effect was monitored according to the formula:

$$
I \%=\frac{1-E}{C} 100 \%,
$$

where: I\% - percent of inhibition; E - No. of local lesions on the experimental halves of the leaf, C- No. of local lesions on the control halves of the leaf. All the treatments were made in triplicate on plants of a similar age and size grown in a greenhouse.

In electron microscopic studies $0.4 \mathrm{ml}$ of a mixtures containing $0.2 \mu \mathrm{g} / \mathrm{ml} \mathrm{TMV}$ and $1 \mathrm{mg} / \mathrm{ml}$ or $2 \mathrm{mg} / \mathrm{ml}$ of LPS, lipid A or carbohydrate fraction of LPS were incubated at room temperature during $30 \mathrm{~min}$ (TMV was used as a control), then samples were prepared for research using transmission electron microscope (TEM). The samples were applied to copper grids with a formvar solution and kept for $15 \mathrm{~min}$. After adhesion of the test material to the substrate, negative contrasting with a $2 \%$ aqueous solution of phOPShotungstic acid (PTA) was carried out during $20 \mathrm{~s}$. Then the samples were washed by keeping them in distilled water for $5 \mathrm{~s}$ and dried in air at room temperature. The analysis of the finished samples was carried out using a JEM 1400 TEM (Jeol, Japan) at an accelerating voltage of $80 \mathrm{kV}$.

For statistical processing of the obtained research results, the software package StatSoft STATISTICA 10.0.1011 was used. The determination of the mean and the error of the mean values $(\mathrm{M} \pm \mathrm{m})$ were carried out by the parametric method using the Student's t-test. A p value $<0.05$ was considered significant.

Results. In the present study, we report the in vitro antiviral activities and interaction of LPS and its structural components with TMV, since the effect of the product "Gaupsin" on the antiviral activity were previously shown $[10,11]$. LPS from nine strains of the phytopathogenic phytopathogenic bacterium $P$. agglomerans were isolated and chemically characterized by us earlier [17-23]. The individual structural components of the LPS macromolecule was obtained by mild acid hydrolysis, in which insoluble lipid A and water-soluble O-specific polysaccharide (OPS) and core oligosaccharide (OG-core) fractions were obtained. The lipid A precipitate was separated by ultracentrifugation. The water-soluble products of LPS hydrolysis were separated by gel permeation chromatography on a column $(70.0 \times 3.0 \mathrm{~cm})$ with Sephadex G-50 and it was shown that LPS represent a mixture of S- and R-type molecules, as evidenced by the presence of a high-molecular weight fraction OPS (fraction I) and low molecular weight fractions of OG-core (fraction II and III) (Fig. 1).

The effect of $P$. agglomerans LPS preparations and their structural components on the infectivity of viruses in vitro have been studied. The antiviral activity of LPS was assessed on Datura stramonium L. plants hypersensitive to TMV, which are characterized by the localization of the virus in the primary foci of infection in the form of local necrotic lesions that can be easily counted [24].

In Table 1, the results showed that studied LPS preparations at a concentration of $1 \mathrm{mg} / \mathrm{ml}$ exhibited an inhibitory activity against TMV infection in vitro ranged from 18 to $60 \%$. It was observed that the LPS samples from P. agglomerans P324 and 8488 were the most effective in reducing the number of local lesions and the antiviral activity reached $59-60 \%$. Inhibition of the virus infectivity by $31-39 \%$ was induced by LPS preparations of P. agglomerans $8674 \mathrm{t}, 7460,7460$ succinilated, $\mathrm{P} 1 \mathrm{a}$ and 9649. The in vitro effect of LPS preparations of P. agglomerans 7969, 7604 and 9637 against TMV was insignificant (19-24\%). It should be noted that the antiviral activity of the preparations did not decrease under environmental temperature up to $50{ }^{\circ} \mathrm{C}$ which sometime could be reached in the greenhouse conditions in June. This phenomenon can be explained both by the high point of temperature inactivation of the virus, $68-84{ }^{\circ} \mathrm{C}$ (for some strains, $84-95^{\circ} \mathrm{C}$ ) [25], and by the thermal stability of LPS preparations. Modification of the original LPS 7460 by succinylation did not lead to a change in antiviral activity.

The differences in the antiviral activities of different LPS preparations may be attributed to their structural features. Thus, comparative analysis of the antiviral activity of LPS structural components of two P. agglomerans P324 and 7604 strains showed (Table 2) that the greatest inhibitory effect on the infectivity of TMV had P. agglomerans $\mathrm{P} 324$ lipid A, the antiviral activity of which did not differ a lot from the activity of LPS molecule (it was lower by $7 \%$ ). The fractions of OG-core from P. agglomerans $\mathrm{P} 324$ and lipid A 
from $P$. agglomerans 7604 were revealed as weak inhibitors of TMV in vitro. At the same time, the inhibitory effect of the carbohydrate structural components of P. agglomerans 7604 (especially OG-core - II and III fractions) compared with the effect of the whole LPS molecule against TMV was slightly higher. It can be assumed that the OG-core stimulates the defense mechanisms of plants and prevents the development of viral infection.

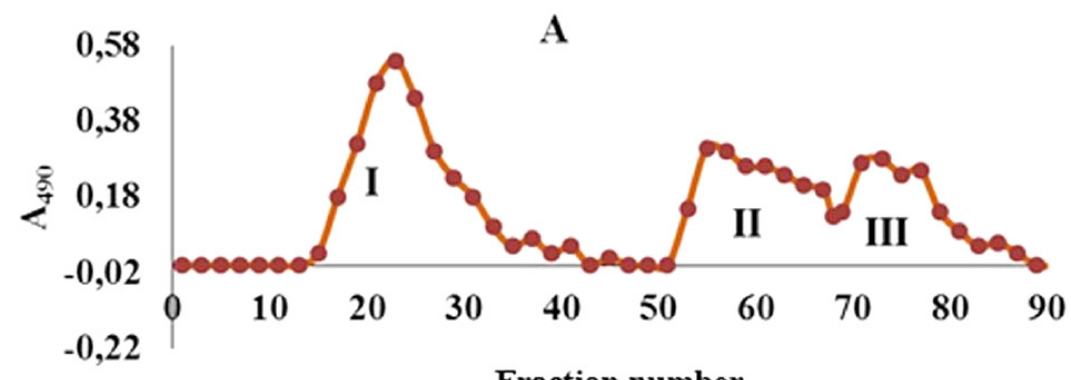

Fraction number

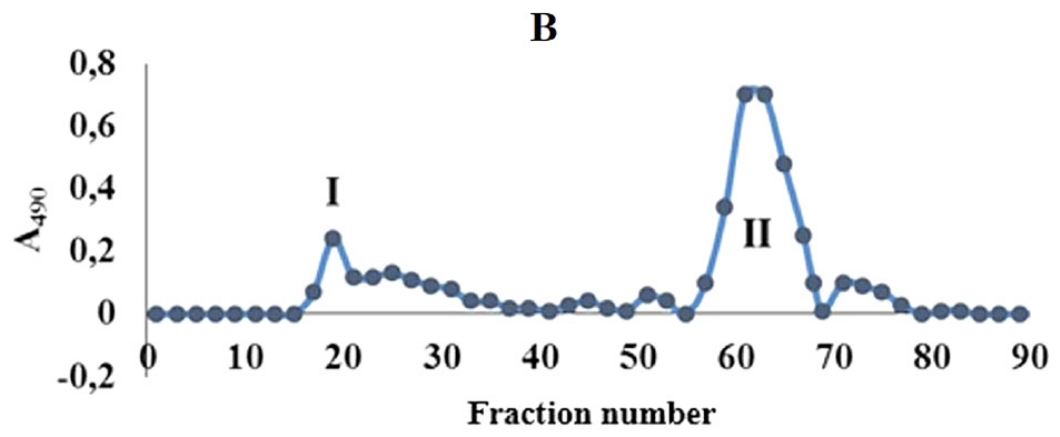

F i g. 1. Elution profiles of the carbohydrate moiety of the degraded LPS molecule from P. agglomerans 7604 (A) and P324 (B) on Sephadex G-50. I - OPS fraction; II-III - OG-core fractions

Table 1

The influence of P. agglomerans strains LPS on the infectivity of TMV

\begin{tabular}{|l|c|c|c|c|}
\hline \multirow{2}{*}{ LPS of $\boldsymbol{P}$ agglomerans strains: } & \multicolumn{2}{|c|}{ Number of local lesions } & \multirow{2}{*}{ E/C } & \multirow{2}{*}{ I, \% } \\
\cline { 2 - 3 } & experience & control & & 39 \\
\hline $8674^{\mathrm{T}}$ & 41.0 & 59.0 & $0.71 \pm 0.07$ & 37 \\
\hline 7460 & 49.5 & 73.0 & $0.63 \pm 0.06$ & 31 \\
\hline $7460_{\text {suc }}$ & 62.8 & 74.1 & $0.69 \pm 0.08$ & 31 \\
\hline P1a & 59.6 & 85.8 & $0.69 \pm 0.03$ & 60 \\
\hline P324 & 36.3 & 90.3 & $0.40 \pm 0.08$ & 59 \\
\hline 8488 & 32.0 & 79.0 & $0.41 \pm 0.05$ & 24 \\
\hline 7969 & 72.0 & 94.2 & $0.76 \pm 0.08$ & 21 \\
\hline 7604 & 77.0 & 99.8 & $0.79 \pm 0.04$ & 19 \\
\hline 9637 & 98.1 & 120.6 & $0.81 \pm 0.05$ & 32 \\
\hline 9649 & 64.3 & 94.6 & $0.68 \pm 0.07$ & \\
\hline
\end{tabular}

Bacteria and their products can both positively and negatively affect the stability and infectivity of viruses. Bacterial molecules such as LPS are large enough carbohydrate polymers that can contact with binding sites on the surface of virions. Since LPS are composed of many smaller repeating subunits, it is possible that viruses can interact with these molecules at several binding sites. Therefore, we were interested in the effect of the studied LPS and their structural components on TMV during their direct interaction in vitro. Electron microscopic dates have shown (Fig. 2) that P. agglomerans P324 LPS at the concentration of $1 \mathrm{mg} / \mathrm{ml}$ influenced on freely located virions in the control (Fig. 2, A) causing their "sticking together" thus forming dense clusters, complexes or "bundles" of the virus. The data indicate a direct interaction between P. agglomerans LPS and TMV. At the same time, under the influence of LPS at a concentration of $2 \mathrm{mg} / \mathrm{ml}$ (Fig. 2, B), no "sticking" of viral particles 
was found. Viral particles surrounded the LPS molecules, thereby preventing them from sticking together, forming dense clusters.

The individual structural components of P. agglomerans P324 LPS (lipid A and OG-core) did not have the same effect as a whole molecule
(Fig. 3). It was observed the weak adhesion of viral particles. This phenomenon can be initial stages of consequent dense clusters forming.

Thus, the study of the antiviral activity of LPS in the model system TMV - Datura stramonium L. plants showed that the most active were LPS

Table 2

Inhibition of TMV infection by LPS structural components of $P$. agglomerans strains on Datura stramonium L. plants

\begin{tabular}{|c|c|c|c|c|c|}
\hline \multirow{2}{*}{\multicolumn{2}{|c|}{$\begin{array}{c}\text { LPS structural components of } \\
\text { P. agglomerans strains: }\end{array}$}} & \multicolumn{2}{|c|}{ Number of local lesions } & \multirow{2}{*}{$\mathbf{E} / \mathbf{C}$} & \multirow{2}{*}{$\mathbf{I}, \%$} \\
\hline & & experience & control & & \\
\hline \multirow{4}{*}{$\stackrel{ \pm}{\pi}$} & LPS & 36.3 & 90.3 & $0.40 \pm 0.08$ & 60 \\
\hline & II Fraction & 128.5 & 149.5 & $88 \pm 5$ & 12 \\
\hline & Lipid A & 57.3 & 217.5 & $47 \pm 8$ & 53 \\
\hline & I Fraction & 103.0 & 176.6 & $62 \pm 8$ & 38 \\
\hline \multirow{5}{*}{$\underset{8}{\mathbb{D}}$} & LPS & 77.0 & 99.8 & $0.79 \pm 0.04$ & 21 \\
\hline & III Fraction & 126.0 & 198.0 & $64 \pm 6$ & 36 \\
\hline & II Fraction & 105.2 & 148.8 & $71 \pm 7$ & 29 \\
\hline & Lipid A & 186.0 & 217.6 & $83 \pm 10$ & 17 \\
\hline & I Fraction & 114.6 & 148.7 & $77 \pm 6$ & 23 \\
\hline
\end{tabular}
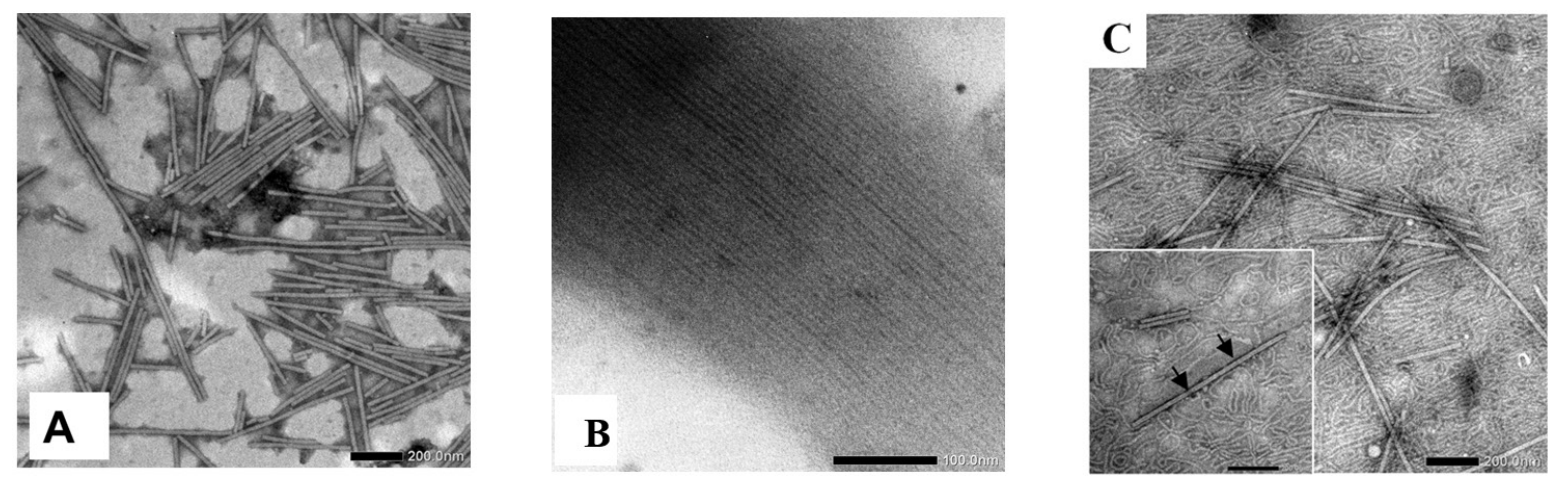

F i g. 2. Electron micrographs of the TMV and LPS interactions: A - TMV (control); B - a mixture of TMV and P. agglomerans P324 LPS (1 mg/ml); C - a mixture of TMV and P. agglomerans P324 LPS (2 mg/ml). Arrows show the junctions of sticking viral particles.
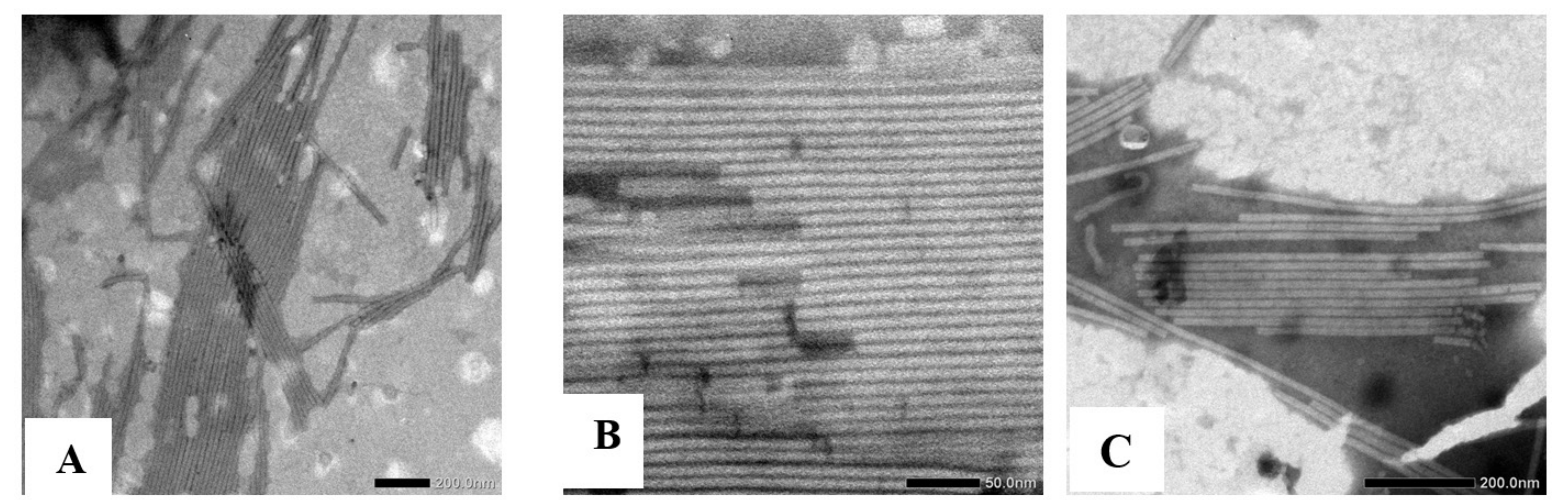

F i g. 3. Electron micrographs of the TMV and LPS structural components interactions: A - a mixture of TMV and P. agglomerans P324 Lipid A $(1 \mathrm{mg} / \mathrm{ml}) ; \mathrm{B}-$ a mixture of TMV and P. agglomerans P324 Lipid A ( $2 \mathrm{mg} / \mathrm{ml})$; C - a mixture of TMV and P. agglomerans P324 OG-core $(2 \mathrm{mg} / \mathrm{ml})$. 
obtained from only two strains of $P$. agglomerans (P324 and 8488) while the other seven strains were inactive. Individual structural components: lipid A from $P$. agglomerans $\mathrm{P} 324$ and $\mathrm{OG}$-core from $P$. agglomerans 7604 decreased the infectivity of TMV by 7 and $15 \%$ more than the initial LPS molecule. According to the electron microscopy data, the virions stuck together forming the dense clusters in case of the direct LPS-virus contacting in vitro whereas in the control it was observed just a single free virus particles.

Discussion. As a result of our earlier studies [9], a high antiviral activity of Pseudomonas chlororaphis subsp. aureofaciens LPS was established. It was shown that they suppressed the infectivity of TMV in the model of three species of indicator plants Nicotiana tabacum, Nicotiana sanderae, and Datura stramonium. It should be noted that LPS [9] obtained from microorganisms belonging to other genera and species (Rahnella aquatilis and Ralstonia solanacearum) did not inhibit the infectivity of TMV in vitro, and sometimes even exhibited a stimulating effect on the virus. In this regard, the question arises whether the effect of LPS from $P$. chlororaphis subsp. aureofaciens in relation to TMV is unique, or it is also typical for LPS of other bacterial species. The choice of $P$. agglomerans strains is due to the fact that representatives of this species are widespread in nature, especially in plants. To date, the antiviral activity of $P$. agglomerans LPS against phytopathogenic viruses has not been studied. Since the structures of OPS and lipids A of some of the studied $P$. agglomerans strains were established by us earlier [17, 21], the purpose of our work was to study the antiviral activity of both LPS molecules and their individual structural components: OPS, OG-core and lipid A in vitro.

The study of the antiviral activity of $P$. agglomerans LPS in vitro on the infectivity of TMV showed that their inhibitory effect varied significantly depending on the strain from which they were obtained. Thus, most of the studied LPS at a concentration of $1 \mathrm{mg} / \mathrm{ml}$, added to an inoculum, containing TMV, inhibited the infectivity of the virus on Datura stramonium leaves by 18 $60 \%$. The degree of inhibition of local lesions on leaves was 59-60\% in the case of using LPS preparations from $P$. agglomerans P324 and 8488.

The structure of the OPS of these strains was significantly different and presented by linear disaccharide: $\rightarrow 3)-\alpha$-L-Rhap-( $1 \rightarrow 4)-\alpha$-D-Glcp-
$(1 \rightarrow(P$. agglomerans P324 [20]) or linear tetrasaccharide: $\rightarrow 3)-\alpha$-L-Rhap- $(1 \rightarrow 6)-\alpha-\mathrm{D}-\mathrm{Man} p$ $(1 \rightarrow 3)-\alpha-L-F u c p-(1 \rightarrow 3)-\beta-D-G 1 c N A c p-(1 \rightarrow$ (P. agglomerans 8488 [21]). This gives us grounds to assume that the peculiarities structure of the OPS don't play a significant role in the effect of LPS on the infectivity of TMV in relation to the indicator plant.

Since lipid A from P. agglomerans P324 exhibited the greatest and $P$. agglomerans 7604 the least inhibitory effect on the infectivity of TMV, we carried out a comparative analysis of their structures. Thus, the structure of lipid A from $P$. agglomerans P324 are represented by hexa- (4 residues 14:0(3-OH), 1 residue 18:0 and 1 residue 12:0) and tetraacyl (3 residues 14:0 (3-OH), 1 residue 12:0) forms. The structure of P. agglomerans 7604 lipid A is represented by penta- (4 residues 14:0 (3-OH), 1 residue 12:0) and tetraacyl ( 3 residue 14:0 $(3-\mathrm{OH}), 1$ residue 12:0) forms [17]. Comparative analysis allows us to assume that the antiviral activity of the LPS molecule is determined by the presence of precisely the hexaacyl form of lipid A.

It should be noted that some researchers associate the high biological activity of LPS, in particular endotoxic, with the presence of the hexaacyl form of lipid A [26].

Earlier [9], when studying the antiviral activity of individual structural components of the LPS molecule of $P$. chlororaphis subsp. aureofaciens B-111 and B-306 in relation to TMV, we have shown that OPS of both strains did not inhibit TMV, and sometimes stimulated its development by 10 $26 \%$ in all tested plant-indicator models. At the same time, the OG-core fractions (fractions II and III) inhibited the development of viral infection to varying degrees. We were unable to study antiviral activity of lipid A of LPS from $P$. chlororaphis subsp. aureofaciens B-111 and B-306, since these fractions turned out to be toxic for indicator plants. At the same time, according to the literature $[5,7]$, the protective effect of LPS is due to a part of the LPS molecule containing both lipid A and the associated OG-core.

The results of studies on the effect of LPS from $P$. agglomerans indicate that the activity of the initial LPS molecule is determined by the structural features of lipid A. A more detailed study of the effect of individual structural components will help to understand the regularities of the effect of LPS structure on TMV infectivity. 


\section{Thanks for the culture}

The team of authors is grateful to the senior researcher of the Department of Phytopathogenic Bacteria IMV NAS of Ukraine Doctor of biologycal sciences L.A. Pasichnik and leading engineer N.V. Zhitkevich for the Pantoea agglomerans culture provided for research.

\section{ВПЛИВ ЛІПОПОЛІСАХАРИДІВ PANTOEA AGGLOMERANS HA IНФЕКЦЮЮ ВТМ В УМОВАХ IN VITRO}

\section{Т.В. Булигіна, А.М. Кириченко, М.С. Харчук, Л.Д. Варбанець}

Інститут мікробіології і вірусології ім. Д.К. Заболотного НАН України, вул. Академіка Заболотного, 154, Київ, 03143, Україна

\section{Резюме}

В останні роки було показано, що ліпополісахариди (ЛПС) деяких бактерій, зокрема представники роду Pseudomonas, були активні проти вірусу тютюнової мозаїки (ВТМ). Тому нас цікавило додаткове вивчення ЛПС фітопатогенних бактерій Pantoea agglomerans як можливих противірусних препаратів. Метою даної роботи було оцінити противірусну активність ЛПС, отриманих із фітопатогенних бактерій $P$. agglomerans щодо ВТМ в дослідах in vitro. Методи. ЛПС P. agglomerans були виділені із сухої бактеріальної маси воднофенольним методом. М'яка кислотна деградація ЛПС дозволила виділити О-специфічний полісахарид (ОПС) та ліпід А, структури яких були ідентифіковані нами раніше. Противірусну активність препаратів ЛПС досліджували in vitro на моделі вірусу тютюнової мозаїки (BTM, штам U1), очищеному із системно інфікованих рослин видів Nicotiana tabacum L. сортів Імунний 580 (ревертант). Аналіз взаємодії ВТМ і ЛПС проводили за допомогою трансмісійного електронного мікроскопа JEM 1400 (Jeol, Японія) при прискорювальній напрузі 80 кВ. Результати. Активними були ЛПС P. agglomerans П324 та 8488, противірусна активність яких становить 59-60 \%. Препарати

1. Hansen AF. Antiviral chemicals for plant disease control. Critical Reviews in Plant Sciences. 1989; 8:45-88.

2. Wang ZW, Wang L, Ma S, Liu YX, Wang LZ, Wang QM. Design synthesis, antiviral activity,
ЛПС P. agglomerans 7969, 7604 та 9637 були неактивними щодо ВТМ в дослідах in vitro. Порівняльний аналіз противірусної активності структурних компонентів ЛПС двох штамів P. agglomerans П324 та 7604 показав, що найбільший інгібуючий ефект на інфекційність ВТМ проявляв ліпід А P. agglomerans П324, противірусна активність якого практично не відрізнялася від активності молекули ЛПС (вона була нижчою на 7 \%). У той же час інгібуюча дія олігосахариду кору P. agglomerans 7604 у порівнянні з ефектом всієї молекули ЛПС проти ВТМ була трохи вищою. Можна припустити, що олігосахарид кору стимулював захисні механізми рослин і запобігав розвитку вірусної інфекції. Дані електронно-мікроскопічного дослідження показали, що ЛПС P. agglomerans П324 у концентрації 1 мг/мл впливав на вільно розташовані віріони в контролі, викликаючи «склеювання їх», утворюючи, таким чином, щільні скупчення, комплекси або «пучки» вірусу. Окремі структурні компоненти ЛПС P. agglomerans П324 (ліпід А та олігосахарид кору) не мали такого ефекту, як нативна молекула. Висновки. Дослідженнями противірусної активності ЛПС у модельній системі BTM -Datura stramonium L. показано, що найбільш активними були ЛПС лише двох штамів P. agglomerans (П324 та 8488), тоді як інші сім штамів були неактивними. Окремі структурні компоненти - ліпід А P. agglomerans П324 та олігосахариди кору P. agglomerans 7604 зменшували інфекційність ВТМ на 7 і 15 \% відповідно, що більше, ніж молекула ЛПС. Згідно з даними електронної мікроскопії, віріони склеювались, утворюючи щільні скупчення під час безпосереднього контакту вірусу і ЛПС в дослідах in vitro, тоді як у контролі спостерігали поодинокі вільно розташовані частинки вірусу. Більш детальне вивчення впливу окремих структурних компонентів ЛПС допоможе зрозуміти закономірності впливу структури ЛПС на інфекційність ВТМ.

Ключові слова: ліпополісахариди Pantoea agglomerans, ліпід А, олігосахариди кору, вірус тютюнової мозаїки, пригнічення інфекційності, електронна мікроскопія.

and SARs of 14-aminophenanthroindolizidines. J Agric Food Chem. 2012; 2(60):5825-5831.

3. Wang ZW, Wei P, Liu YX, Wang QM. D and E rings may not be indispensable for antofine: discovery of phenanthrene and alkylaminechain 
containing antofine derivatives as novel antiviral agents against tobacco mosaic virus (TMV) based on interaction of antofine and TMV RNA. J Agric Food Chem. 2014; 62:10393-10404.

4. Yucheng Yao, Xueshun Yu, Zhide Yu. Plant antiviral agent, preparation method and application thereof. WO 2007/1090014 AO 1N65/08.

5. Shuster G, Kluge Z, Kovalenko AG. [Sredstvo borby s virusami rasteniy]. Patent RF № 2036583 AO 1N 63/00. Russian.

6. Yuki D, Kiso A. Method and agent for controlling plant disease using bacteria of genus Bacillus. United States Patent N US 2009/0175837 C 12N 1/20, AO 1N 63/00.

7. Miller SH, Mark GL, Franks AO, Gara F. Pseudomonas - Plant Interactions: Pseudomonas. Model Organism, Pathogen, Cell Factory. B. H. Rehm, editor. Weinheim: Wiley-VCH Verlag; 2008. P. 353-370.

8. Naoto S, Hanae K, Yoshitake D. Resistance-inducing agent for disease of monocotyledonae. JP 2007-03-29 N 2007077065 (A), AO1N63/00, AO1N63/02.

9. Kiprianova EA, Varbanets LD, Shepelevich VV. Voichuk SI. Antiviral activity of lipopolysaccharides of Pseudomonas chlororaphis subsp. aureofaciens. Biotechnologia acta. 2013; 6(2):68-73.

10. Avdeeva LV, Balko OI, Kiprianova EA, Kovalenko OG. Pseudomonas aureofaciens and biopreparation Haupsin. New aspects of biological activity. Abstracts of the XII Congress of Vynograds'kyj Society of Microbiologists of Ukraine. 2009:282.

11. Balko OI, Kiprianova EA, Kovalenko AG, Shepelevych VV, Avdeeva LV. Antiphytoviral activity of Gaupsin biopreparat. Microbiology and Biotechnology. 2010; 2(10):12-17.

12. Galanos C, Tanaka A. Biological activities of chemically modifiend endotoxins. Eur J Biochem. 1971; 22:218-224.

13. Dubois M, Gilles KA, Hamilton JK. Colorimetric method for determination of sugars and related substances. Anal Chem. 1956; 28(3):350-356.

14. Hebert TT. Precipitation of plant viruses by polyethylene glycol. Phytopathology. 1963; 53:362.

15. Chen J, Yan XH, Dong JH, Sang P, Fang X, Di YT, Zhang ZK, Hao XJ, Tobacco Mosaic Virus
(TMV) Inhibitors from Picrasma quassioides Benn. J Agric Food Chem. 2009; 57:6590-6595.

16. Yan XH, Chen J, Di YT, Fang X, Dong JH, Sang P, Wang YH, He HP, Zhang ZK, Hao XJ. Anti-tobacco mosaic virus (TMV) quassinoids from Brucea javanica (L.) Merr. J Agric Food Chem. 2010; 58:1572-157.

17. Zdorovenko EL, Kadykova AA, Shashkov AS, Varbanets LD, Bulyhina TV, Knirel YuA. Lipopolysaccharides of Pantoea agglomerans 7604 and 8674 with structurally related O-polysaccharide chains: Chemical identification and biological properties. Carbohydr Polymers. 2018; 181:386-393

18. Zdorovenko EL, Kadykova AA, Shashkova AS, Varbanets LD, Bulyhina TV, Knirel YA. Lipopolysaccharide of Pantoea agglomerans 7460: O-specific polysaccharide and lipid A structures and biological activity. Carbohydrate Research. 2020; 496:108132. DOI: 10.1016/j.carres.2020.108132.

19. Zdorovenko EL, Kadykova AA, Shashkov AS, Varbanets LD, Bulyhina TV. Pantoea agglomerans P1a lipopolysaccharide: Structure of the $\mathrm{O}$-specific polysaccharide and lipid A and biological activity. Carbohydrate Research. 2019; 484:1-5.

20. Zdorovenko EL, Kadykova AA, Shashkov AS, Varbanets LD, Bulyhina TV, Toukach PV. Structure and Biological Properties of the O-specific Polysaccharide and Lipid A from Pantoea agglomerans P 324. Microbiology. 2021; 90(1):96105.

21. Bulyhina TV, Zdorovenko EL, Varbanets LD, Shashkov AS, Kadykova AA, Knirel YuA, Lushchak OV. Structure of O-Polysaccharide and Lipid A of Pantoea agglomerans 8488. Biomolecules. 2020; 10(5):804

22. Zdorovenko EL, Kadykova AA, Shashkova AS, Varbanets LD, Bulyhina TV, Knirel YA. Lipopolysaccharide of Pantoea agglomerans 7969: chemical identification, function and biological activity. Carbohydrate Polymers. 2017; 165:351358 .

23. Bulyhina TV, Varbanets LD, Pasichnyk LA. Lipopolysaccharide of Pantoea agglomerans 9649: chemical identification and biological activity. 
Mikrobiol Z. 2018; 80(2):56-66.

24. Dijkstra J, de Jager CP. Infectivity Assay on Local-Lesion Hosts. In: Practical Plant Virology. Springer Lab Manual. Springer, Berlin, Heidelberg. 1998. https://doi.org/10.1007/978-3-64272030-7_10
25. Price W.C. Thermal inactivation rates of four plant viruses. Archiv Virusforschung. 1940; $1: 373-386$.

26. Seydel U, Schromm A, Blunck, Branderburg K. Chemical structure, molecular conformation, and bioactivity of endotoxins. Chem Immunol. 2000; $74: 5-24$.

Received 17.12.2020 